\title{
小なろ導體の電氣抵抗測定法
}

$\begin{array}{lll}\text { 阿 } & \text { 部 } & \text { 淸 } \\ \text { 豐 } & \text { 田 } & \text { 實 }\end{array}$

\section{1, 序}

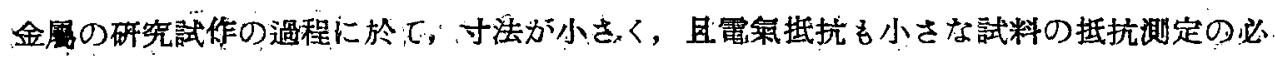

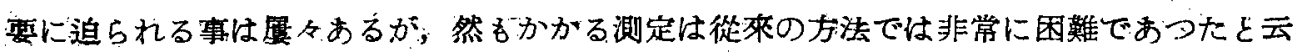

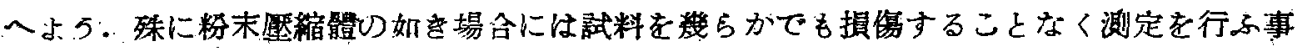
は一有团難であつた。

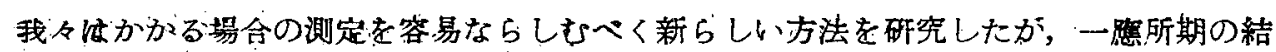
果を得たので，茲に報告する次第である。

\section{2. 裝 置 $の$ 概 要}

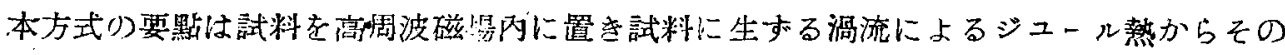
㜪抗を求むる事にある事にある。

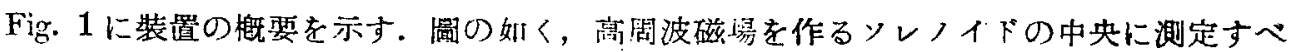
き試料と，ベークライト(試料と同形闹人のもり) を吊し，各々に銅とコンスタンタン上り成る熱䨪

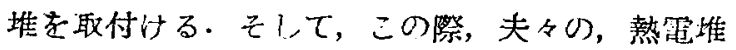
の熱起電力が互に打消し合心奶くに接䅡し，ての 端に檢流計を接續ずる・裝置としては圖の他に， ソレノイドの高周波雪澈流寸電源としての高周

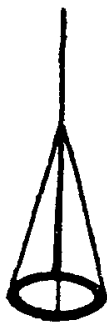

Fig. 2 波發雪機或ひは高周波發振器があれ 仗良い。

試料の形は洽流を利用する故圆塼 牀とする. 刃此の試料定另すには

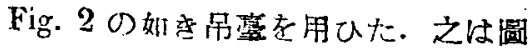
の如く輪形心薄い稖母片を四本の糸 で吊したもので，之の上に試料を醀

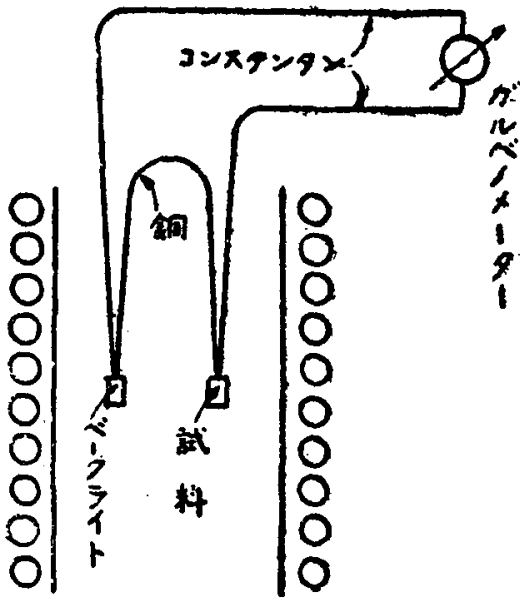

Fig. 1 定出來るのつである。

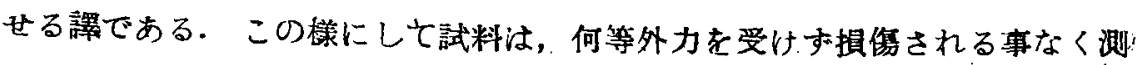




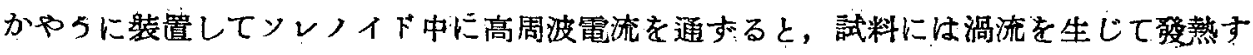
るが，一方ソレノイトの導線自身は，導線中の電流に上つて，溫度上昇を來寸ので，此の 影響を補貲する篇にべークライトを設けたのである。

かくして交番磁場內に試料を置けば，或時間後には溫度の上昇は停止して本衡狀態に達 する.此の時の溫度を，檢流計の振れから知れば，夯の項に述へる理由に上りその固有抵 抗が求めら礼るのである。

\section{3. 理}

論

先つ，渦流によつて試料に生する發熱量 $\mathrm{Pw} / \mathrm{cm} .^{3}$ を求めると，周知心梯に，(例へば森 光三氏著「ベッセル函數と其の應用」窑照）

$$
\cdot \mathrm{P}=4 \pi \mathrm{n}^{2} \mu\left(m \mathrm{I}^{2} \mathrm{~N} \times 10^{-9} \mathrm{w} / \mathrm{cm}^{3}\right.
$$

となるここに $\mathrm{N}=\frac{2}{\mathrm{Ka}} \cdot \frac{\text { berKa.ber'Ka+beiKa. bei'Ka }}{\text { ber" Ka+bei' } \mathrm{Ka}}$

$$
\begin{aligned}
& \mathrm{K}=\left(4 \pi \boldsymbol{m}_{\mu} / \rho\right)^{1 / 2} \\
& \mathrm{n}=\text { ンレノイトの單位舆以撩數 } \\
& \mathrm{I}=\text { ソレノイド中の高周波電流(A) } \\
& \omega=2 \pi \mathrm{f} \text { (但, } \mathrm{f} \text { \&高周波電流の周波數〉 } \\
& \mu=\text { 試料の導磁承 } \\
& \rho=\text { 試料め體積固有抵抗 (e.m.u.) } \\
& \mathrm{a}=\text { 試料刀本徑 }(\mathrm{cm})
\end{aligned}
$$

猶，上式より明かなる如く，す以外の變數中 $\mu$ を除いては，總て容易に知ら礼るが， $\mu$ のみはそ5でない，故に我ふの䁈驗に於ては， $\mu=1$ の物のみを扱つた。 從つて, 以下便宜上

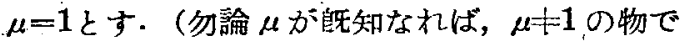
も何等差支人ない)

次に

$$
\begin{aligned}
& \theta=\text { 試料の溫度上型 }\left({ }^{\circ} \mathrm{C}\right) \\
& \mathrm{C}=. " \text { 比熱 } \\
& \mathrm{M}=\text { ＂質量 }(\mathrm{g}) \\
& \mathrm{V}=. " \text { 體皘 }\left(\mathrm{cm}^{3}\right) \\
& \mathrm{S}=\text { “ ”表面積 }\left(\mathrm{cm}^{2}\right) \\
& \mathrm{h}=\text { " 冷却係數 }\left(\mathrm{w} / \mathrm{cm}^{2}\right)
\end{aligned}
$$

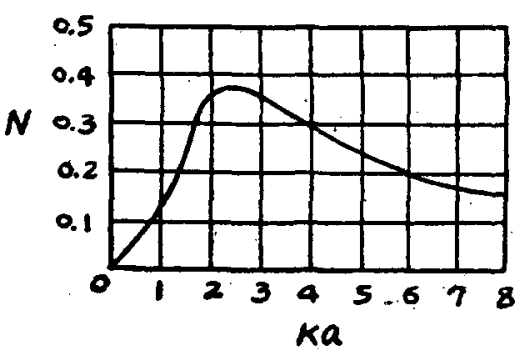

Fig.3

とすると，渦流による發熱量 $\mathrm{P}$ と之等の間には，次の關係が成立つ。

$$
\mathrm{PVdt}=\mathrm{cMd} \theta+\mathrm{hS} \theta \mathrm{dt}
$$

之のPに (1) 式を入れてて解くのであるが， $\mathrm{P}$ 中の可變數は $\mathrm{n}, \omega, \mathrm{I}, \mathrm{N}$ であり，その中 $\mathrm{n}, \omega$, I，は测定中一定となし得，又Nは Kaの函數であるが，Kaは（3）式より知られる如く， 


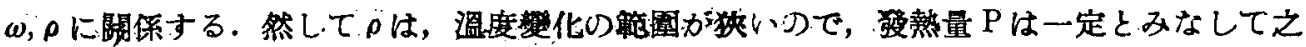
の微分方程式を解く事が出來る。“すると結局次の樣になる。

$$
\mathrm{N}=\frac{\mathrm{hS}}{\mathrm{AV}} \theta_{\infty}
$$

ここに, $\theta_{\infty} \cdots=$ 平衡狀態に於ける試料の溫度上界 $\left({ }^{\circ} \mathrm{C}\right)$

$$
\mathrm{A}=4 \pi \mathrm{n}^{2} \omega \mathrm{I}^{2} \times 10^{-9}
$$

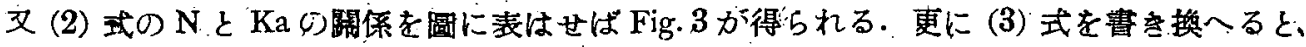

$$
\rho=\frac{4 \pi \omega \mathrm{a}^{2}}{(\mathrm{Ka})^{2}}\left(=\frac{4 \pi \omega}{\mathrm{K}^{2}}\right)
$$

となる。

故に（5）式に於て A, S, V,hを豫め測定及び計算して括けば $\theta_{\infty}$ を知ればNが直ちに求

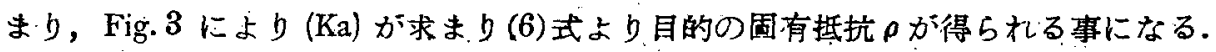

唒 (5)式に於て $\mathrm{A}, \mathrm{S}, \mathrm{V}$ は明かな睡知量であるが，冷却係數 hは少しく問題があり，その 定め方に就て一言する．冷却係數は物體の表面の狀態のみに關係する（主としてとの色に 關係する)，故に各試料の表面に同一门紙を貼付する事に上り，先つ各試料の h は同一と

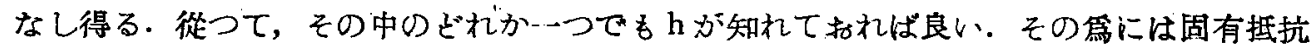
既知の金屬に就下同樣の試驗を行つて $\theta_{\infty}$ を求むれで，此の場合は $\rho$ 既知なる故逆の手順 だんが得られる譯である，又冷却係數は漓溫になると溫度に上つて變化するが，我々の場 合は $100^{\circ} \mathrm{C}$ 以下であるから不變と考へてよい。

\section{4. 測定結果と注意事項}

我ふの用ひた試料は，直徑 $1 \mathrm{~cm}$ 長さ $1.3 \mathrm{~cm}$ 程度の圆壔である. 高周波電源としては， 出力 $1 \mathrm{~kW}$ ，端子電壓 $100 \mathrm{~V}$, 周波數 500 サイっルの高周波發電機を用ひた.ゾレノイトは內 徑 $6 \mathrm{~cm}$, 外徑 $11 \mathrm{~cm}$, 高さ $20 \mathrm{~cm}$ 總港国数 456 , 自己誘望係数約 $7.6 \mathrm{mH}$ である.そして之 に約 TAの電流を流しで・猶試料の溫度上算の程度は；最も低抵抗の銅で約 $30^{\circ} \mathrm{Cであつた。}$ 他は勿論それ以下である。

こひ樣な留を置を用ひて测定した結 果を右表に示す，考心篇に，電氣 エ學ボケットブックに記載され゙る 同種の金属の抵捝值併記したが， 椙當接近した值を示してるる. 猶表 中, $\mathrm{Cu}_{1}$ は研究害の手近にあつ方銅

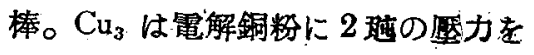

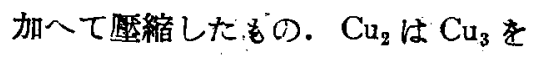

\begin{tabular}{|c|c|c|c|c|}
\hline & 抵抗値 & $\left(\begin{array}{cc}\text { at } 20^{\circ} \mathrm{D} \\
\mu \Omega & \mathrm{cm} .\end{array}\right)$ & 比 & 重 \\
\hline 料 & 測 定 值 & P.B. 記载值 & 湘 定 值 & P.B. 毁載值 \\
\hline $\mathrm{Bi}$ & 131 & 115 & 9.67 & 9.8 \\
\hline $\mathrm{Sb}$ & 46.3 & 40 & 6.67 & 6.6 \\
\hline $\mathrm{Pb}$ & 22. & 21.9 & 11.13 & 11.37 \\
\hline Sin & 12.9 & 11.4 & 7.33 & 7.35 \\
\hline $\mathrm{Cd}_{4}$ & 7.1 & 7.5 & 8.50 & 8.65 \\
\hline $\mathrm{Zn}$ & 6.3 & 6.1 & 7.00 & 7.14 \\
\hline $\mathrm{Cu}_{1}$ & 1.9 & 1.69 & 9.20 & 8.92 \\
\hline $\mathrm{Cu}_{2}$ & 4.1 & $\longrightarrow$ & 6.75 & - \\
\hline $\mathrm{Cu}_{3}$ & 38 & - & 6.75 & - \\
\hline
\end{tabular}

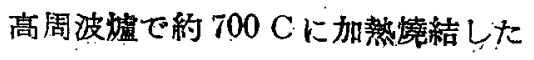
るすを示す・その他の諸鈔は何れ

（註） P.B.は電策工學ボケットブックを指す 


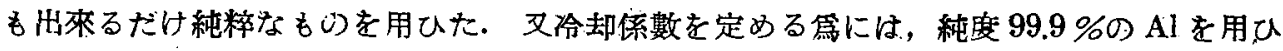
た.

次に本筫驗に於て吟味すべき事項に就て述へる。

a）(1)式は無限長の圓濤に就て得られたるすである故,長さ $1.3 \mathrm{~cm} \cdot 0$ 樣に短い場合には 誤差を生するるもひと考へ，之を檢討する爲 Cdに就て䄪 5 倍の長さの試料を作り測定した が餘り差は認められなかつた。此仙，hを求める際にも(1) 式を用ひてるるので，そこで 相殺されてるるとも考へら礼るが，更に他の長い試料を入手の上確めて見たい。

b) 抵抗の大なる金屬では，检流計の振れが小さいので誤差が大きくなる傾向がある.

(それはソレノイド自身の發熱の影響が大きく效くや5になるからでもある)。その爲に 周波數を高的て望驗を行ふ豫定であるが一般的に言つて，Kaが1〜2の範圍にある樣に試 料に應じて周波數を選ぶ事は有效であら5.

c) ソッノイドの贽熱の影響を補償するに用ひたベークライトは，熱傅導率が金屬と同 じ程度の非金虽例へば陶器等を用ひる方が望ましいと考へられる。

d) その他本方式に於ける誤差の原因としては（4）式を解く際に抵抗り溫度係數を無視

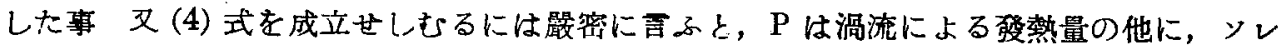
ノイド自身の發熱に基くエネルギーをも合めねばならぬが，それを無視した事（但し之 は，平衡狀態に於ける溫度上昇として渦流に基くもののみを探るやらにしてるる爲，之に 基く誤差は相常小さくなり或昜合には全くなくなる。）及び冷却俰數を紙の貼付により一 樣なりと見做した事. 等が考へられる.

最後に，浿定に際して注意すべき事は，天候によつて给却係數が多少變化する事である。

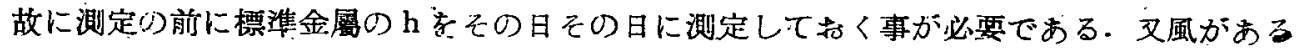
とソレノイド中の空氣を動播せしめて, 溫度上昇の狀態を變化せしめるから，ンレノィト を圍つて拓く事が望ましい。

\section{5. 結言}

以上要するに，本方式によれば，從來の例へば電崕降下法等では，殆ど不可能であつた 樣な寸洼，抵抗共に非常に小さな導體の抵抗が，容易に測定し得られっ，然も試料には全く 外力が加はら爲に損傷される事はなく, 又精度も，未だ吟味の餘地があるが相當高いる 言へよう.

終りに臨み，各種の金屬を御提供下された，冶金學政室教授西村博士に對して深甚なる 謝意を表し.ます。 